\title{
Evaluation of the ERCC2 (Lys751GIn), MSH2 (gIVS12-6TC), RAD54 (Ala730Ala), XPC (Lys939GIn), XPG (Asp1104Hist), XRCC1 (Arg399GIn) and XRCC3 (Thr241Met) gene polymorphisms in the Ecuadorian population with retinoblastoma
}

Paola E. Leone ( $\nabla$ paola.leone@ute.edu.ec)

Universidad UTE Facultad de Ciencias de la Salud Eugenio Espejo https://orcid.org/0000-0003-33512275

\section{Patricia Guevara-Ramírez}

Universidad UTE Facultad de Ciencias de la Salud Eugenio Espejo

\section{Silvana Quevedo}

Universidad UTE Facultad de Ciencias de la Salud Eugenio Espejo

\section{Sonia Zumárraga}

Hospital de Niños Baca Ortiz

Isaac Armendáriz-Castillo

Universidad UTE Facultad de Ciencias de la Salud Eugenio Espejo Jennifer M. García-Cárdenas

Universidad UTE Facultad de Ciencias de la Salud Eugenio Espejo

\section{Santiago Guerrero}

Universidad UTE Facultad de Ciencias de la Salud Eugenio Espejo Andrés López-Cortés

Universidad UTE Facultad de Ciencias de la Salud Eugenio Espejo

Andy Pérez-Villa

Universidad UTE Facultad de Ciencias de la Salud Eugenio Espejo

\section{Verónica Yumiceba}

Universidad UTE Facultad de Ciencias de la Salud Eugenio Espejo

\section{Ana Karina Zambrano}

Universidad UTE Facultad de Ciencias de la Salud Eugenio Espejo

César Paz y Miño

Universidad UTE Facultad de Ciencias de la Salud Eugenio Espejo

Research article 
Keywords: retinoblastoma, repair genes, ERCC2, MSH2, RAD54, XPC, XPG, XRCC1, XRCC3, Ecuadorian population

Posted Date: July 24th, 2019

DOI: https://doi.org/10.21203/rs.2.11870/v1

License: (c) (1) This work is licensed under a Creative Commons Attribution 4.0 International License. Read Full License 


\section{Abstract}

Background Retinoblastoma is a neoplasia that starts in the retina and may have inheritable or sporadic genetic predisposition. This affects children, mainly those who are under 5 years old. Approximately 9,000 new cases are diagnosed per year worldwide. In Ecuador this disease has an incidence of 1 per each 20,000 live births. The genetic predisposition to develop retinoblastoma is strongly influenced by RB1 gene, and may be influenced by the presence of genetic polymorphisms which intervene in the DNA repair system. Methods This study has analyzed the genotype frequency of ERCC2 (Lys751GIn), MSH2 (gIVS12-6TC), RAD54 (Ala730Ala), XPC (Lys939GIn), XPG (Asp1104Hist), XRCC1 (Arg399GIn), and XRCC3 (Thr241Met) polymorphisms of different repair genes, genotyping 90 individuals affected with retinoblastoma and 80 healthy individuals through polymerase chain reaction / restriction fragments length polymorphism and sequencing analysis. Results The presence of the $(\mathrm{C} / \mathrm{C})$ mutant homozygous genotype of XPC (Lys939GIn) polymorphism triggers a significant risk of developing retinoblastoma with an odds ratio $(\mathrm{OR})$ of $3(\mathrm{Cl}: 1.22-9.84 ; \mathrm{p}<0.05)$. Likewise, the $A / G$ heterozygous genotype and the combination $\mathrm{A} / \mathrm{G}+\mathrm{G} / \mathrm{G}$ of XRCC1 (Arg399GIn) polymorphism presented ORs of 9.7 (Cl: 4.45-21.08; $p<$ 0.001 ) and 7.55 (IC: $3.57-16 ; p<0.001$ ), respectively. Conclusions The genetic variants XPC (Lys939GIn) and XRCC1 (Arg399GIn) may be associated with the risk of developing retinoblastoma in the Ecuadorian population.

\section{Background}

Retinoblastoma $(\mathrm{Rb})$ is a neoplasia characterized by the presence of malignant tumors in the retina. According to the Union for International Cancer Control, 95\% of individuals are diagnosed before being 5 years old. Rb has an incidence of 1 per each 15,000-20,000 live births worldwide, and it accounts for 3\% of all the cancer cases affecting children [1-3]. In Ecuador, according to the Cancer National Records by SOLCA, the incidence of this neoplasia is of 1 per 20,000 live births [4]. In developing countries, including Peru, Bolivia, Ecuador and India, the incidence of Rb increases since most of the cases are not detected on time due to the lack of access to health services $[2,3]$.

Most cancers find a way to impair $R B 1$ function, either through direct mutation of the $R B 1$ gene or, more commonly, through the altered expression of $R B 1$ regulators, which include cyclin $\mathrm{D}, \mathrm{CDK} 4$ and $\mathrm{CDK} 6$, and their principal inhibitor, p16 [5]. RB1 is a multi-functional protein involved in a wide range of biological processes including transcriptional regulation by recruiting chromatin remodelling enzymes, DNA replication via interaction with DNA polymerase complex components, apoptosis and plays a central role in DNA repair [6]. In addition, proteins from the Rb family use their amino-terminal domains to interact with other proteins and recognize DNA damage [7].

$R B 1$ is the tumor suppressor gene responsible for retinoblastoma. Rb usually occurs when both alleles of the $R B 1$ get inactivated in a precursor retinal cell, which is followed by mutations in some other specific genes. Both alleles may be lost from a retinal cell from which a tumor arises (nonheritable Rb or sporadic $\mathrm{Rb}$ ) developing a somatic mutation, or it could be a germ line mutation (heritable $\mathrm{Rb}$ ), in which case, there 
is a predisposition for the development of multiple retinal tumors during childhood and even other cancers later in life [8]. Heritable RB encompasses $45 \%$ of all reported cases with bilateral $(80 \%)$, unilateral (15\%), or trilateral (5\%) tumors [9].

On the other hand, DNA damage may be caused by endogen or hexogen factors. The endogen damages are mainly caused by free radicals, accelerating the rupture of DNA chains. Ionizing radiation and UV radiation cause hexogen damages responsible for the rupture of chain or pyrimidine dimers [10]. The DNA repair processes are important to eliminate different types of damage caused by those endogen or hexogen factors. Nucleotide excision repair (NER), base excision repair (BER), mismatch repair (MMR), and homologous recombination repair

(HR) are pathways to repair genetic material [11].

Some repair gene polymorphisms may affect the function of the protein that alters the capacity of repairing DNA, causing genetic instability and carcinogenesis. NER is responsible for repairing damage with voluminous adducts and thymine dimers. The ERCC2, XPC, and XPG genes are important members of this pathway $[12,13]$. BER repairs damage caused by ionizing radiation or through alkylation replacing the mutated base with the correct nucleotide. The XRCC1 gene is involved in this pathway, and codifies a protein that facilitates the repair carried out by hexogen factors. The Arg399GIn polymorphism of the $X R C C 1$ gene has a functional importance on the gene and could alter repair capacity and could influence cancer susceptibility $[14,15]$. The $M S H 2$ gene is involved in DNA repair due to mismatch. $M S H 2$ is found in the short arm of the chromosome 2. In order to be able to perform its function of DNA repair, it must work together with other proteins, such as MSH6 and MSH3. It was previously found that the gIVS126TC polymorphism, which involves a replacement of $\mathrm{T}$ with $\mathrm{C}$ in an intron junction site, has been associated with the development of lymphomas. This polymorphism was found in $7.52 \%$ of the normal individuals (allele frequency of 0.05 ) and in $22.73 \%$ of the lymphomas (allele frequency of 0.11 ) $[16,17]$.

One of the main mechanisms to repair the rupture of DNA double chain is HR because it repairs the genetic material during cell replication [18]. The XRCC3 gene is part of the repair by HR, its Thr241Met polymorphism could be associated with the damage in the repair function since replacing methionine with threonine may influence the function of the enzyme through the elimination of a phosphorylation site [19]. The RAD54 gene also repairs DNA by HR and meets the function of modifying the topology of double-stranded DNA. RAD54 encodes a protein of 747 amino acids; it is member of the SNF2 family and depends on DNA-ATPase. This gene was previously associated with the development of meningioma [20].

Single-nucleotide polymorphisms (SNPs) present in the previously explained genes may drive the development of $\mathrm{Rb}$ in Ecuador. Therefore, the objective of this research was to study the association of several SNPs of the DNA repair genes ERCC2 (Lys751GIn), MSH2 (gIVS12-6TC), RAD54 (Ala730Ala), XPC (Lys939GIn), XPG (Asp1104Hist), XRCC1 (Arg399GIn) and XRCC3 (Thr241Met) with the risk of developing $\mathrm{Rb}$ in the Ecuadorian population. 


\section{Methods}

\section{Biological samples}

The Bioethics Committee of the Universidad de las Americas approved this retrospective study (20150401) following the Declaration of Helsinki. A total of 170 individuals were included into the analysis. Concerning the 90 individuals with Rb, DNA from peripheral blood samples and paraffin-embedded tumor samples were collected per patient between the years 1999 and 2015 from the Solón Espinosa Ayala Oncological Hospital (SOLCA), Baca Ortiz Children's Hospital, Metropolitano Hospital, and Eugenio Espejo Hospital. All referred cases to these hospitals were captured including their respective medical history. With regards to control group, peripheral blood samples $(n=80)$ were obtained randomly from healthy children who did not suffer from $\mathrm{Rb}$, did not present family antecedents of $\mathrm{Rb}$, and went through a routine

test at the Baca Ortiz Children's Hospital. Furthermore, all the participants signed their respective informed consent.

\section{DNA Extraction}

Histopathologists reviewed all tissue sections of paraffin-embedded tumors of the affected group. Subsequently, DNA was extracted from the area of interest (tumor tissue). Ten sections (10 $\mu \mathrm{m}$ thick) were cut and deparaffinized using a standard protocol. Genomic DNA was extracted using a protocol based on the High Pure PCR template preparation kit (Roche, USA) following the manufacturer's instructions. DNA extraction from peripheral blood (controls and cases) was carried out by means of the PureLinkTM Genomic DNA kit (Invitrogen, USA). quantification of the extracted DNA was performed through the spectrophotometer NanodropTM 2,000 (Thermo Scientific, USA).

\section{Genotyping}

Regarding the affected individual cases, genotyping was performed analyzing DNA from paraffinembedded tumor samples in order to correlate them with the genotypes from the blood samples. The genomic DNA from all individuals was amplified by the polymerase chain reaction (PCR), using specific primers for each polymorphism of the different repair genes (Table 1). Each reaction consists of $8.13 \mu$ l of water Mili-Q, $1.5 \mu \mathrm{l}$ of genomic DNA (50-100 ng/ $\mu \mathrm{l}), 10 \mathrm{mM}$ of each deoxynucleoside triphosphate (dNTPs), $10 \mathrm{mM}$ of each primer, $3 \mathrm{mM}$ of $\mathrm{MgCl}_{2}, 1 X$ Buffer of PCR and $5 \mathrm{U}$ of Taq Polymerase (Invitrogen; Thermo Fisher Scientific, Inc.) in a total volume of $15 \mu$. The PCR program for all the polymorphisms was carried out in a thermocycler Sure Cycler 8800 (Agilent, Santa Clara, CA), and consists of an initial denaturalization of 5 minutes at $95^{\circ} \mathrm{C}$, followed by 35 cycles of 1 minute at $94^{\circ} \mathrm{C}$, 45 seconds at different annealing temperatures, being $67^{\circ} \mathrm{C}$ for the $E R C C 2$ gene, $51^{\circ} \mathrm{C}$ for $M S H 2,62^{\circ} \mathrm{C}$ for $R A D 54,64^{\circ} \mathrm{C}$ for $X P C$, $61^{\circ} \mathrm{C}$ for $X P G, 60^{\circ} \mathrm{C}$ for $X R C C 1$ and $62^{\circ} \mathrm{C}$ for $X R C C 3$, finishing with an elongation at $72{ }^{\circ} \mathrm{C}$ for 5 minutes. 
The fragments amplified for the ERCC2 (Lys751GIn), XPC (Lys939GIn), XPG (Asp1104Hist), XRCC1 (Arg399GIn), and XRCC3 (Thr241Met) polymorphisms were digested with $5 \mathrm{U}$ of the Pstl, Pvull, Hsp92II, Msp/and N1/alll enzymes, respectively. The digested fragments were divided by conventional agarose gel electrophoresis in $4 \%$ agarose gel dyed with ethidium bromide and the genotypes were identified through amplicon observation under the UV light of the transilluminator. The products of the digestion of the different polymorphisms are detailed in Table 2. The MSH2 (gIVS12-6TC) and RAD54 (Ala730Ala) polymorphisms were directly sequenced after amplification. The genotyping analysis of these last polymorphisms and the confirmation of the genotypes obtained by enzyme digestion were made by the genetic analyzer 3130 (Applied Biosystems, Austin, TX) using the BigDye Terminator v.3.1 kit (Applied Biosystems, USA).

\section{Statistical Analysis}

Each patient's clinical background was analyzed. Genotyping frequencies, allele frequencies, and HardyWeinberg equilibrium were calculated for the different polymorphisms. through the IBM SPSS version 11.5 program, the following tests were carried out: odds ratio (OR) (with a $2 \times 2$ contingency table and a 95\% confidence interval) and $p$-values in order to determine the association between SNPs and the risk of developing $\mathrm{Rb}$.

\section{Results}

The analysis included 90 cases of retina cancer and 80 controls from the Ecuadorian population. The relevant information of the studied population is shown in Table 3. The patients have a mean age of 3 years, being $51.11 \%$ males and $48.89 \%$ females. All patients underwent enucleation surgery for the removal of the eye at risk. As for the control group, blood samples were collected from 80 healthy individuals of $1-6$ years old and a mean age of 3.40 years, being $62.50 \%$ males and $37.50 \%$ females. Regarding the age ranges, individuals between 2 and 5 years old had a non-significant risk (OR) of 1.35 (IC: $0.43-4.33 ; p=0.77$ ), and individuals under 2 years old had a non-significant OR of 1.32 (IC: $0.36-$ $4.64 ; p=0.68$ ) in developing $\mathrm{Rb}$, compared to the reference group (children older than 5 years). According to laterality, $81.11 \%$ of cases were unilateral, $17.78 \%$ were bilateral and $1.11 \%$ was trilateral.

Figure 1 shows the distribution of all 90 cases with Rb in 20 Ecuadorian provinces. The Sierra Region (the Highlands) presented $60 \%$ of cases followed by the Coast Region (25.60\%) and the Amazon Basin (14.40\%). The provinces with the most cases of Rb were Pichincha (28.90\%), Guayas (11.10\%), Imbabura (7.80\%), Santo Domingo (6.70\%), Sucumbíos (5.60\%) and Chimborazo (5.60\%). Regarding the type of Rb, 73 cases were unilateral, of which $58.90 \%$ were from Sierra, $26 \%$ from Coast and $15.10 \%$ from the Amazon Basin; 16 cases were bilateral, of which $68.80 \%$ were from Sierra, $25 \%$ from Coast and $6.20 \%$ from the Amazon Basin; finally, the only trilateral case was from the Amazon Basin.

Table 4 shows the genotype distribution and allele frequencies of the studied SNPs. The genotypes of the ERCC2 (Lys751GIn), XPC (Lys939GIn), XPG (Asp1104Hist), XRCC1 (Arg399GIn), and XRCC3 
(Thar241Met) genetic polymorphisms were obtained according to the band pattern shown in agarose gel resulting from the enzyme digestion; the presence of the genotypes of each polymorphism was verified by means of electropherograms of sequences, excepting $M S H 2$ and $R A D 54$ which were directly analyzed by the electropherograms obtained in the sequencing process. The genotype frequencies of the study group, excepting those of the XPG gene, were in Hardy-Weinberg equilibrium. The frequency of the allele $\mathrm{C}$ of ERCC2 was higher in cases (0.13) than controls (0.12). The frequency of the allele T of $M S H 2$ was higher in cases (0.06) than controls (0.04). The frequency of the $C$ allele of $X P C$ was higher in cases $(0.48)$ in contrast with controls $(0.36)$. The allele frequency of the $\mathrm{G}$ allele of $X R C C 1$ was higher in cases (0.46) than controls (0.29). Lastly, the allele frequency of the $\mathrm{G}$ allele of $X R C C 3$ was higher in cases $(0.10)$ than controls (0.08).

Table 5 shows the association between different polymorphisms of repair genes and the risk of developing retina cancer. The statistical analysis has given rise to a higher risk of $\mathrm{Rb}$ in presence of certain genotypes of the $X P C$ and $X R C C 1$ genes. The risk was 3.47 times higher for the group with the $(C / C)$ mutant homozygous genotype of the $X P C$ gene $(\mathrm{OR}=3.47 ; \mathrm{Cl}: 1.22-9.84 ; \mathrm{p}=0.03)$. In addition to that, risk was observed for the heterozygous genotype $(\mathrm{A} / \mathrm{G})$ of the $X R C C 1$ gene with an OR of $9.74(\mathrm{Cl}$ : 4.45-21.08; $\mathrm{p}<0.01$ ). On the other hand, the different genotypes of the ERCC2, MSH2, RAD54, XPG and $X R C C 3$ genes had no significant risk in developing $\mathrm{Rb}$ in the Ecuadorian population.

\section{Discussion}

Li et al (2013) performed an enrichment analysis of genes related to Rb through Gen Ontology (G0) and the Kyoto Encyclopedia of Genes and Genomes (KEGG) pathway database [21, 22]. They determined that 119 genes were related to $\mathrm{Rb}$ compared to normal retina. The enrichment analysis of the 119 genes generated $2 \mathrm{GO}$ terms with significant false discovery rate $(F D R)<0.01$ relevant for Rb: cell cycle (G0:0007049) and M phase of mitotic cell cycle (GO:0000087). For KEGG analysis, only the cell cycle pathway (hsa04110) was significantly enriched. However, the most influential gene in retinoblastoma is $R B 1[21,22]$.

$\mathrm{Rb}$ is caused by mutations of the $R B 1$ gene altering functional proteins, triggering cell division in the retina, and leading to the development of tumors [23]. According to Leone et al (2003), a previous study in Ecuadorians with $\mathrm{Rb}$ has described new mutations and SNPs [24]. For instance, a mutation found in exon 15 with a replacement of $\mathrm{G}$ to $\mathrm{A}$ (g.76920 G>A), and a mutation found in exon 22 with a replacement of $T$ to $C$ (g.IVS22-14 T>C). Additionally, three SNPs were found, two were deletions in introns 15 (g.76983) and 16 (g.78064) and the third one was a transition $\mathrm{C}$ to $\mathrm{T}$ in intron 26.

On the other hand, several mechanisms are involved in the development of Rb such as the disruption of the DNA repair system [25]. The genomic alteration of this system has been associated with other types of cancer such as colorectal cancer (CRC) [26], glioma [27], lung cancer [28, 29], head and neck squamous cell carcinoma [30], melanoma [31] and breast cancer [32]. 
The disruption of the DNA repair system may be caused by the inter-individual variability in the capacity of repairing the genetic material, due to the presence of SNPs in several DNA repair genes found in coding or regulating regions [33]. The $X P C, X P D, X P G, X R C C 1$ and $X R C C 3$ repair genes may present polymorphisms leading to replacement of amino acids that may affect the function of theresulting proteins. These changes occur in a relatively high frequency, affecting this way a wide section of the world population [34]. The deficient result to DNA damage caused by hexogen and endogen agents may lead to genetic alterations in the DNA repair pathway, triggering serious biological effects [35].

NER pathway is involved in the elimination of short segments of nucleotides that have damaged bases by exposure to UV radiation. Important members of this pathway are ERCC2, XPC, and XPG. ERCC2 synthesizes the XPD protein [36]. This protein is an essential subunit of a group of proteins called transcription factor IIH (TFIIH) complex. This complex is involved in gene transcription process and it helps to repair damaged DNA. According to Lanara et al (2013), a huge meta-analysis study has demonstrated that ERCC2 Lys751GIn is positively correlated with breast and lung cancers [37], and this study contributes in understanding the association between this SNP and Rb in Ecuador.

A higher frequency of the A allele (0.58) was obtained for the Lys939GIn polymorphism of the XPC gene, whereas the $C$ allele was represented by 0.42 . In contrast with a meta-analysis that studied 679 cases of several types of cancer and 902 controls, the most prevalent allele was A with 0.62 [38], coinciding the allele frequency of the studied population. In a meta-analysis made in a Chinese population, the Lys939GIn polymorphism was significantly associated with the risk of CRC in the A/C heterozygous pattern $(\mathrm{OR}=1.40, \mathrm{Cl}$ of $95 \%=1.16-1.69 ; \mathrm{p}<0.05)$ [39]. Another research demonstrated that the patients with the $\mathrm{C} / \mathrm{C}$ genotype have 2.09 times more risk of developing bladder cancer than normal A/A genotype [40]. In this study was found that the $\mathrm{C} / \mathrm{C}$ genotype has 3.47 times more risk of developing retina cancer than a normal A/A genotype ( $<$ 0.05). According to He et al (2013), the risk of developing any type of cancer may be assumed due to the fact that the polymorphisms of the XPC gene may influence the capacity of DNA repair and the function of the protein of an individual, affecting genetic instability and modifying predisposition to cancer, since this gene is involved in the recognition of DNA damage; thus, $X P C$ is the main component to initiate NER pathway [41].

Several studies have shown that SNPs of the XPG gene are associated with several cancers. The Asp1104Hist polymorphism helped to increase the risk of CRC [25, 42]. He et al (2014) reported a significant decrease in the risk of melanoma for the $\mathrm{C} / \mathrm{C}$ genotype $(\mathrm{OR}=0.32 ; \mathrm{Cl}$ of $95 \%=0.13-0.75 ; \mathrm{p}<$ $0.05)$ [25]. In other studies a statistically significant risk of prostate cancer in individuals with $\mathrm{C} / \mathrm{C}$ genotype $(\mathrm{OR}=2.53, \mathrm{Cl}$ of $95 \%=0.99-6.56 ; \mathrm{p}<0.05)$ was found. Concerning $\mathrm{Rb}$, we had no significant results for $\mathrm{G} / \mathrm{C}+\mathrm{C} / \mathrm{C}$; thus, these are not associated with the disease $(\mathrm{OR}=0.47, \mathrm{Cl}: 0.23-0.97, \mathrm{p}>0.05)$.

BER pathway repairs the oxidative DNA damage caused by alkylating agents. The $X R C C 1$ gene is an important component of this pathway. The Arg399GIn polymorphism of the $X R C C 1$ gene showed more frequency of $\mathrm{G}$ allele (0.63) in contrast with A allele (0.37). Vaezi, Feldman, \& Niedernhofer (2011) suggest that the mutant $\mathrm{G}$ allele correlates with lower capacity of DNA repair, leading to increased 
genomic instability and sensibility to agents that damage DNA [43]. In a meta-analysis of CRC, the frequency of $\mathrm{G}$ allele was significantly different among three populations, being highest in the black population (0.83), intermediate in Taiwanese origin $(0.74)$, and lowest in whites $(0,63)$. These differences suggest a possible ethnic variability in allele distribution of XRCC1 [44]. Another study analyzed 1,635 patients with cervical cancer and 2,361 controls, showing that the Arg399GIn polymorphism decreases the susceptibility of such cancer ( $\mathrm{G}$ vs. A: $\mathrm{OR}=0.39$, Cl of $95 \%=0.29-0.51 ; p<0.05$ ) [45]. In a metaanalysis in the Caucasian populations, it was found that the $A / G$ and $G / G$ genotypes were associated with the risk of developing lung cancer [46]. Likewise, a meta-analysis showed that the association between the Arg399GIn polymorphism and the risk of prostate cancer is affected by ethnicity; significantly marked associations were found among Asians, rather than African people [47]. In the current study it was also found an association between the Arg399Gln polymorphism with the risk of developing retina cancer for $A / G$ genotype $(O R=9.74 ; \mathrm{Cl}: 4.45-21.08 ; p<0.05)$, as well as for the combined genotype A/G + G/G (OR = 7.55; Cl: 3.57-16.00; $p<0.05)$.

MMR pathway plays an important role in maintaining genomic stability and repairs damage mainly caused in base-base imbalance and the insertion/deletion errors generated during DNA replication and recombination [48]. MSH2 belongs to this repair pathway. In a study on patients with lymphoma, it was found that $22.73 \%$ of these individuals had a replacement of T with $\mathrm{C}$ in intron junction site of the $\mathrm{MSH}$, whereas only $7.50 \%$ of the same variation was observed in normal individuals $(p<0.01)$; consequently, the allele frequency of the group was 0.95 for the T allele, 0.05 for the $C$ mutant allele, and there were no homozygotes for the $\mathrm{C}$ allele in the group with lymphoma, suggesting this replacement probably influences susceptibility to cancer because it is twice more often in people who have developed lymphoma, rather than a non-carcinogenic population [17]. In this research no significant differences were obtained for the $\mathrm{C} / \mathrm{T}$ heterozygote $(\mathrm{OR}=1.43 ; \mathrm{Cl}$ : $0.46-3.92 ; \mathrm{p}>0.05)$, which suggests that such polymorphism has no association with the risk of $\mathrm{Rb}$.

Several replication errors cause double-chain breaks that are generated by hexogen agents, such as ionizing radiation. The pathway that repairs such damages is homologous recombination to which the RAD54 and XRCC3 genes belong. As for the RAD54 gene, according to Paz-y-Miño et al (2010), a statistically significant association was found between frequencies calculated for the subgroup with chronic myelogenous leukemia (0.14), in contrast with the control group [49]. Concerning meningioma, an association between the T allele and the development of meningioma tumor $(p<0.05)$ was found [20]. In this research an association of the $R A D 54$ with $\mathrm{Rb}$ was not found ( $\mathrm{OR}=0.63 ; \mathrm{Cl}: 0.25-1.52 ; \mathrm{p}>0.05$ ). Regarding the $X R C C 3$ gene, in an analysis of melanoma a significant association of the T/T genotype and cancer (TT versus CC: $\mathrm{OR}=1.06 ; \mathrm{Cl}$ of $95 \%=0.87-1.29$ ) was found. Another study showed a protective effect in the individuals with the $\mathrm{C} / \mathrm{C}$ genotype (OR: $0.32 ; \mathrm{p}<0.05$ ), whereas the T/T mutant genotype indicated that the risk of developing lung cancer is 4 times higher. In this study a statistically significant association with $R b$ was not found since the OR was of 1.31 for $C / T+T / T$ with a $p>0.05$.

\section{Conclusions}


The RB1 gene has been associated with different pathways that are involved in the development of cancer such as DNA repair. Consequently, according to the evidence obtained in this research, it is suggested that $\mathrm{Rb}$ is directly related to the NER $(X P C)$ and BER (XRCC1) repair pathways.

\section{Abbreviations}

Rb: Retinoblastoma; NER: Nucleotide excision repair; BER: base excision repair; MMR: mismatch repair; HR: homologous recombination repair; SNPs: Single-nucleotide polymorphisms; PCR: polymerase chain reaction; dNTPs: deoxynucleoside triphosphate; OR: odds ratio; KEGG: Kyoto Encyclopedia of Genes and Genomes; CRC: colorectal cancer; TFIIH: transcription factor IIH.

\section{Declarations}

\section{Acknowledgements}

We want to thank to Solón Espinosa Ayala Oncological Hospital (SOLCA), Baca Ortiz Children's Hospital, Metropolitano Hospital, and Eugenio Espejo Hospital for their support in this research.

\section{Funding}

Not Applicable.

\section{Availability of data and material}

All data generated or analyzed during this study are included in this published article. All these data supports the conclusions of the study.

\section{Authors' contributions}

PEL designed the study and wrote the manuscript. PGR performed the experiments and wrote the manuscript. SQ performed the data collection of clinic history. SZ was the pathologist and histopathologically analyzing the paraffin-embedded tumor samples. IAC, JMGC, SG, ALC, AP, VY and AKZ analyzed the data. CPyM supervised the research project. All authors read and approved the final manuscript.

\section{Ethical approval and consent to participate}

This study was approved by the Bioethics Committee of the Universidad de las Americas (2015-0401) and met the tenets of the Declaration of Helsinki, and informed consent was obtained from all of the 
subjects prior to the study.

\section{Consent for publication}

Not applicable

\section{Competing interests}

The authors have no conflict of interest to declare.

\section{References}

1. Fabian ID, Onadim Z, Karaa E, Duncan C, Chowdhury T, Scheimberg I, et al. The management of retinoblastoma. Oncogene. 2018;37(12):1551-60.

2. Dine J, Gordon R, Shames Y, Kasler MK, Barton-Burke M. Immune Checkpoitn Inhibitors: An Innovation in Immunotherpay for the Treatment and Managment of Paatients With Cancer. Asia Pac J Oncol Nurs. 2017;4(3):127-35.

3. Ortiz MV, Dunkel IJ. Retinoblastoma. J Child Neurol. 2016;31(2):227-36.

4. Sociedad de Lucha Contra el Cáncer/Registro Nacional de Tumores; Epidemiología del Cáncer en Quito 2006-2010. 15 ed. Cueva P, Yépez J, editors. Quito; 2014. 245 p.

5. Sherr CJ, McCormick F. The RB and p53 pathways in cancer. Cancer Cell. 2002;2(2):103-12.

6. Huang PH, Cook R, Mittnacht S. RB in DNA repair. Oncotarget. 2015;6(25):20746-7.

7. Huang PH, Cook R, Zoumpoulidou G, Luczynski MT, Mittnacht S. Retinoblastoma family proteins: New players in DNA repair by non-homologous. Mol Cell Oncol. 2016;3(2):1-3.

8. Chawla B, Singh R. Symposium Recent advances and challenges in the management of retinoblastoma. Indian J Ophthalmol. 2017;65(2):133-9.

9. Soliman SE, Racher H, Zhang C, MacDonald H, Gallie BL. Genetics and Molecular Diagnostics in Retinoblastoma - An Update. Asia Pac J Ophthalmol. 2017;6(2):197-207.

10. Clancy S. DNA damage \& repair: mechanisms for maintaining DNA integrity. Nature Education. 2008;1(1):103.

11. Maugeri-Sacca M, Bartucci M, De Maria R. DNA Damage Repair Pathways in Cancer Stem Cells. Mol Cancer Ther. 2012;11(8):1627-36.

12. Hoeijmakers JHJ. DNA Damage, Aging, and Cancer. N Engl J Med. 2009;361(15):1475-85.

13. Zhao Z, Zhang A, Zhao Y, Xiang J, Yu D, Liang Z. The association of polymorphisms in nucleotide excision repair genes with ovarian cancer susceptibility. Biosci Rep. 2018;38(3).

14. Jackson SP, Bartek J. The DNA-damage response in human biology and disease. Nature. 2009;461(7267):1071-8. 
15. Isakova J, Talaibekova E, Aldasheva N, Vinnikov D, Aldashev A. The association of polymorphic markers Arg399GIn of XRCC1 gene, Arg72Pro of TP53 gene and T309G of MDM2 gene with breast cancer in Kyrgyz females. BMC Cancer. 2017;17(1):1-7.

16. Paz-y-Miño C, Fiallo BF, Morillo SA, Acosta A, Giménez P, Ocampo L, et al. Analysis of the polymorphism [gIVS12-6T>C] in the hMSH2 gene in lymphoma and leukemia. Leuk Lymphoma. 2003;44(3):505-8.

17. Paz-y-Miño C, Pérez JC, Fiallo BF, Leone PE. A polymorphism in the hMSH2 gene (gIVS12-6T >C) associated with non-Hodgkin lymphomas. Cancer Genet Cytogenet. 2002;133(1):29-33.

18. Jasin M, Rothstein R. Repair of strand breaks by homologous recombination. Cold Spring Harb Perspect Biol. 2013;5(11):1-18.

19. Mao C, Qian W, Wu J, Sun D, Tang J. Association between the XRCC3 Thr241Met Polymorphism and Breast Cancer Risk: an Updated Meta-analysis of 36 Case-control Studies. Asian Pac J Cancer Prev. 2014;15(16):6613-8.

20. Leone PE, Mendiola M, Alonso J, Paz-y-Miño C, Pestaña A. Implications of a RAD54L polymorphism $(2290 \mathrm{C} / \mathrm{T})$ in human meningiomas as a risk factor and/or a genetic marker. BMC Cancer. 2003;3:18.

21. Li Z, Li BQ, Jiang M, Chen L, Zhang J, Liu L, et al. Prediction and analysis of retinoblastoma related genes through gene ontology and KEGG. Biomed Res Int. 2013;2013: 304029.

22. Ogata H, Goto S, Sato K, Fujibuchi W, Bono H, Kanehisa M. KEGG: Kyoto encyclopedia of genes and genomes. Nucleic Acids Research. 1999;27:29-34.

23. Singh U, Malik MA, Goswami S, Shukla S, Kaur J. Epigenetic regulation of human retinoblastoma. Tumor Biol. 2016;37(11):14427-41.

24. Leone PE, Vega ME, Jervis P, Pestaña A, Alonso J, Paz-y-Miño C. Two new mutations and three novel polymorphisms in the RB1 gene in Ecuadorian patients. J Hum Genet. 2003;48(12):639-41.

25. He X, Liu L, Wei W, Liu Y, Su J, Wang S, et al. Association between the XPG Asp1104His and XPF Arg415GIn polymorphisms and risk of cancer: A meta-analysis. PLoS One. 2014;9(5):e88490.

26. Mort R, Mo L, McEwan C, Melton DW. Lack of involvement of nucleotide excision repair gene polymorphisms in colorectal cancer. Br J Cancer. 2003;89(2):333-7.

27. Chen P, Wiencke J, Aldape K, Kesler-Diaz A, Miike R, Kelsey K, et al. Association of an ERCC1 polymorphism with adult-onset glioma. Cancer Epidemiol Biomarkers Prev. 2000;9(8):843-7.

28. Chen S, Tang D, Xue K, Xu L, Ma G, Hsu Y, et al. DNA repair gene XRCC1 and XPD polymorphisms and risk of lung cancer in a Chinese population. Carcinogenesis. 2002;23(8):1321-5.

29. Park JY, Park SH, Choi JE, Lee SY, Jeon H-S, Cha SI, et al. Polymorphisms of the DNA repair gene xeroderma pigmentosum group $A$ and risk of primary lung cancer. Cancer Epidemiol Biomarkers Prev. 2002;11(10 Pt 1):993-7.

30. Sturgis E, Dahlstrom K, Spitz M, Wei Q. DNA Repair Gene. Head Neck. 2002;128:1084-8. 
31. Trucco LD, Mundra PA, Hogan K, Garcia-Martinez P, Viros A, Mandal AK, et al. Ultraviolet radiationinduced DNA damage is prognostic for outcome in melanoma. Nat Med. 2019;25(2):221-4.

32. López-Cortés A, Paz-y-Miño C, Cabrera-Andrade A, Barigye SJ, Munteanu CR, González-Díaz H, et al. Gene prioritization, communality analysis, networking and metabolic integrated pathway to better understand breast cancer pathogenesis. Sci Rep. 2018;8(1):16679.

33. El-Zein R, Monroy CM, Etzel CJ, Cortes AC, Xing Y, Collier AL, et al. Genetic polymorphisms in DNA repair genes as modulators of hodgkin disease risk. Cancer. 2009;115(8):1651-9.

34. Bănescu C, Trifa AP, Demian S, Benedek Lazar E, Dima D, Duicu C, et al. Polymorphism of XRCC1, XRCC3, and XPD genes and risk of chronic myeloid leukemia. Biomed Res Int. 2014;2014.

35. Maynard S, Schurman SH, Harboe C, de Souza-Pinto NC, Bohr VA. Base excision repair of oxidative DNA damage and association with cancer and aging. Carcinogenesis. 2009;30(1):2-10.

36. Houten B Van, Kuper J, Kisker C. Role of XPD in cellular functions: To TFIIH and beyond. DNA Repair. 2016;44:136-42.

37. Lanara Z, Giannopoulou E, Fullen M, Kostantinopoulos E, Nebel JC, Kalofonos HP, et al. Comparative study and meta-analysis of meta-analysis studies for the correlation of genomic markers with early cancer detection. Hum Genomics. 2013;7:14.

38. Qiu L, Wang Z, Shi X, Wang Z. Associations between XPC polymorphisms and risk of cancers: A meta-analysis. Eur J Cancer. 2008;44(15):2241-53.

39. Hua RX, Zhu J, Jiang DH, Zhang SD, Zhang JB, Xue WQ, et al. Association of XPC Gene Polymorphisms with Colorectal Cancer Risk in a Southern Chinese Population: A Case-Control Study and Meta-Analysis. Genes. 2016;7(10):E73.

40. Rouissi K, Bahria IB, Bougatef K, Marrakchi R, Stambouli N, Hamdi K, et al. The effect of tobacco, XPC, ERCC2 and ERCC5 genetic variants in bladder cancer development. BMC Cancer. 2011;11(1):101.

41. He J, Shi TY, Zhu ML, Wang MY, Li QX, Wei QY. Associations of Lys939GIn and Ala499Val polymorphisms of the XPC gene with cancer susceptibility: A meta-Analysis. Int J Cancer. 2013;133(8):1765-75.

42. Du H, Zhang X, Du M, Guo N, Chen Z, Shu Y, et al. Association study between XPG Asp1104His polymorphism and colorectal cancer risk in a Chinese population. Sci Rep. 2014;4:1-6.

43. Vaezi A, Feldman $\mathrm{CH}$, Niedernhofer LJ. ERCC1 and XRCC1 as biomarkers for lung and head and neck cancer. Pharmgenomics Pers Med. 2011;4(1):47-63.

44. Zhang F, Li B, Wu H, Shang L. Association between X-Ray Repair Cross-Complementing Group 1 Arg399GIn Polymorphism and Cervical Cancer Risk: A Meta-Analysis in the Chinese Population. Gynecol Obstet Invest. 2017;82(4):382-7.

45. Zeng X, Zhang Y, Yue T, Zhang T, Wang J, Xue Y, et al. Association between XRCC1 polymorphisms and the risk of cervical cancer: a meta-analysis based on 4895 subjects. Oncotarget. 2017;8(2):2249-60. 
46. Chen L, Zhuo D, Chen J, Yuan H. XRCC1 polymorphisms and lung cancer risk in Caucasian populations: A meta-analysis. Int J Clin Exp Med. 2015;8(99:14969-76.

47. Yuanyuan M, Xiaoming Y, Lijie Z, Ninghan F. Association between codon 399 polymorphism in the Xray repair cross-complementing group 1 gene and risk of prostate cancer in Asians: A study of 4, 479 cases and 4, 281 controls. Pak J Med. 2015;31(5):1130-5.

48. Li GM. Mechanisms and functions of DNA mismatch repair. Cell Res. 2008;18(1):85-98.

49. Paz-y-Miño C, López-Cortés A, Muñoz MJ, Castro B, Cabrera A, Sánchez ME. Relationship of an hRAD54 gene polymorphism $(2290 \mathrm{C} / \mathrm{T})$ in an Ecuadorian population with chronic myelogenous leukemia. Genet Mol Biol. 2010;33(4):646-9.

\section{Tables}

Table 1. Primer sequences, annealing temperatures, and genetic variations. 


\begin{tabular}{|c|c|c|c|c|}
\hline Gene & Polymorphism & Primer sequence & Fragment (bp) & Annealing temperature $\left({ }^{\circ} \mathrm{C}\right)$ \\
\hline \multirow[t]{3}{*}{ ERCC2 } & Lys751GIn & FW-5'-TCAAACATCCTGTCCCTACTGGCCAT-3' & 343 & 67 \\
\hline & rs13181 & RV-5'-CTGCGATTAAAGGCTGTGGACGTGAC-3' & & \\
\hline & $A / C$ & & & \\
\hline \multirow[t]{3}{*}{ MSH2 } & gIVS 12-6TC & FW-5'-CGCGATTAATCATCAGTG-3' & 353 & 51 \\
\hline & rs2303428 & RV-5'-GGACAGAGACATACATTTCTATC-3' & & \\
\hline & $\mathrm{T} / \mathrm{C}$ & & & \\
\hline \multirow[t]{3}{*}{ RAD54 } & Ala730Ala & FW-5'-AGTGCCCTAACCATTATC- 3' & 258 & 62 \\
\hline & rs 1048771 & RV-5' -TGGAAGACGAAGGTGATA- 3' & & \\
\hline & $\mathrm{C} / \mathrm{T}$ & & & \\
\hline \multirow[t]{3}{*}{$X P C$} & Lys939GIn & FW-5'-ACCAGCTCTCAAGCAGAAGC-3' & 365 & 64 \\
\hline & rs2228001 & RV-5'-GAATCTGACAAGGGCTGGAG-3' & & \\
\hline & $A / C$ & & & \\
\hline \multirow[t]{3}{*}{$X P G$} & Asp1104His & FW-5'-TGGATTTTTGGGGGAGACCT-3' & 159 & 61 \\
\hline & rs17655 & RV-5'-CGGGAGCTTCCTTCACTGAGT-3' & & \\
\hline & $\mathrm{G} / \mathrm{C}$ & & & \\
\hline \multirow[t]{3}{*}{$X R C C 1$} & Arg399GIn & FW-5'-GCCCCTCAGATCACACCTAA-3' & 344 & 60 \\
\hline & rs25487 & RV-5'-AGGTCCTCCTTCCCTCATCT-3' & & \\
\hline & $A / G$ & & & \\
\hline \multirow[t]{3}{*}{$X R C C 3$} & Thr241Met & FW-5'-TTCAGACGGTCGAGTGACAG-3' & 358 & 62 \\
\hline & rs861539 & RV-5'-CCGCATCCTGGCTAAAAATA-3' & & \\
\hline & $\mathrm{C} / \mathrm{T}$ & & & \\
\hline
\end{tabular}

$b p$, base pairs 
Table 2. Enzyme digestion with RFLPs and fragment weights. 


\begin{tabular}{|c|c|c|c|c|}
\hline Gene & Polymorphism & Enzyme & Genotype & Fragment (bp) \\
\hline \multirow[t]{3}{*}{ ERCC2 } & \multirow[t]{2}{*}{ Lys751GIn } & \multirow[t]{3}{*}{ Pstl } & $\mathrm{A} / \mathrm{A}$ & 234,110 \\
\hline & & & $\mathrm{A} / \mathrm{C}$ & $234,172,110,62$ \\
\hline & rs13181 & & $\mathrm{C} / \mathrm{C}$ & $172,110,62$ \\
\hline \multirow[t]{3}{*}{$X P C$} & \multirow[t]{2}{*}{ Lys939GIn } & \multirow[t]{3}{*}{ Puvll } & $A / A$ & 365 \\
\hline & & & $\mathrm{A} / \mathrm{C}$ & $365,250,150$ \\
\hline & rs2228001 & & $\mathrm{C} / \mathrm{C}$ & 250,150 \\
\hline \multirow[t]{3}{*}{$X P G$} & \multirow[t]{2}{*}{ Asp1104His } & \multirow[t]{3}{*}{ Hsp92II } & $\mathrm{G} / \mathrm{G}$ & 159 \\
\hline & & & $\mathrm{G} / \mathrm{C}$ & $159,100,59$ \\
\hline & rs17655 & & $\mathrm{C} / \mathrm{C}$ & 100,59 \\
\hline \multirow[t]{3}{*}{$X R C C 1$} & \multirow[t]{2}{*}{ Arg399GIn } & \multirow[t]{3}{*}{ Mspl } & $\mathrm{G} / \mathrm{G}$ & 184,161 \\
\hline & & & $A / G$ & $344,184,161$ \\
\hline & rs25487 & & $\mathrm{A} / \mathrm{A}$ & 344 \\
\hline \multirow[t]{3}{*}{ XRCC3 } & \multirow[t]{2}{*}{ Thr241Met } & \multirow[t]{3}{*}{ N1lalll } & $\mathrm{C} / \mathrm{C}$ & 341,18 \\
\hline & & & $\mathrm{C} / \mathrm{T}$ & $341,243,100,18$ \\
\hline & rs861539 & & $\mathrm{T} / \mathrm{T}$ & $243,100,18$ \\
\hline
\end{tabular}

bp, base pairs 
Table 3. Baseline characteristics (at diagnosis) of cases and controls. 


\begin{tabular}{|c|c|c|c|c|c|}
\hline Variable & $\begin{array}{l}\text { Cases } \\
\mathrm{n}=90(\%)\end{array}$ & $\begin{array}{l}\text { Controls } \\
\mathrm{n}=80(\%)\end{array}$ & OR & $95 \% \mathrm{Cl}$ & p-value \\
\hline \multicolumn{6}{|c|}{ Gender } \\
\hline Male & $46(51.11)$ & $50(62.50)$ & \multicolumn{3}{|c|}{-} \\
\hline Female & $44(48.89)$ & $30(37.50)$ & & & \\
\hline \multicolumn{6}{|c|}{ Age at diagnosis } \\
\hline$>5$ & $6(6.67)$ & $7(8.74)$ & \multicolumn{3}{|c|}{ Reference (1.0) } \\
\hline $2-5$ & $65(72.22)$ & $56(70.01)$ & 1.35 & $0.43-4.33$ & 0.77 \\
\hline$<2$ & $19(21.11)$ & $17(21.25)$ & 1.32 & $0.36-4.64$ & 0.68 \\
\hline \multicolumn{6}{|c|}{ Type of Rb } \\
\hline Unilateral & $73(81.11)$ & - & \multirow{2}{*}{\multicolumn{3}{|c|}{ - }} \\
\hline Bilateral & $16(17.78)$ & - & & & \\
\hline Trilateral & $1(1.11)$ & - & & & \\
\hline
\end{tabular}

n, number of individuals; $\mathrm{Rb}$, retinoblastoma; $\mathrm{OR}$, odds ratio. 
Table 4. Genotype distribution and allele frequency of single nucleotide polymorphisms. 


\begin{tabular}{|c|c|c|c|c|c|c|c|}
\hline \multirow[t]{2}{*}{ Gene } & \multirow[t]{2}{*}{ Genotype } & \multicolumn{3}{|c|}{ Genotypic frequency } & \multicolumn{3}{|c|}{ Allele frequency } \\
\hline & & Cases & Controls & All & Cases & Controls & All \\
\hline \multirow[t]{3}{*}{ ERCC2 } & $A / A$ & 0.74 & 0.76 & 0.75 & 0.87 & 0.88 & 0.88 \\
\hline & $\mathrm{A} / \mathrm{C}$ & 0.26 & 0.24 & 0.25 & - & - & - \\
\hline & $\mathrm{C} / \mathrm{C}$ & 0.00 & 0.00 & 0.00 & 0.13 & 0.12 & 0.12 \\
\hline \multirow[t]{3}{*}{ MSH2 } & $\mathrm{C} / \mathrm{C}$ & 0.91 & 0.90 & 0.92 & 0.94 & 0.96 & 0.95 \\
\hline & $\mathrm{C} / \mathrm{T}$ & 0.07 & 0.10 & 0.07 & - & - & - \\
\hline & $\mathrm{T} / \mathrm{T}$ & 0.02 & 0.00 & 0.01 & 0.06 & 0.04 & 0.05 \\
\hline \multirow[t]{3}{*}{ RAD54 } & $\mathrm{C} / \mathrm{C}$ & 0.90 & 0.85 & 0.88 & 0.95 & 0.93 & 0.94 \\
\hline & $\mathrm{C} / \mathrm{T}$ & 0.10 & 0.15 & 0.12 & - & - & - \\
\hline & $T / T$ & 0.00 & 0.00 & 0.00 & 0.05 & 0.08 & 0.06 \\
\hline \multirow[t]{3}{*}{$X P C$} & $A / A$ & 0.23 & 0.38 & 0.30 & 0.52 & 0.64 & 0.58 \\
\hline & $A / C$ & 0.58 & 0.54 & 0.56 & - & - & - \\
\hline & $\mathrm{C} / \mathrm{C}$ & 0.19 & 0.09 & 0.14 & 0.48 & 0.36 & 0.42 \\
\hline \multirow[t]{3}{*}{$X P G$} & $G / G$ & 0.31 & 0.18 & 0.24 & 0.65 & 0.58 & 0.62 \\
\hline & $\mathrm{G} / \mathrm{C}$ & 0.68 & 0.81 & 0.75 & - & - & - \\
\hline & $\mathrm{C} / \mathrm{C}$ & 0.01 & 0.01 & 0.01 & 0.35 & 0.42 & 0.38 \\
\hline \multirow[t]{3}{*}{$X R C C 1$} & $A / A$ & 0.13 & 0.54 & 0.34 & 0.54 & 0.71 & 0.63 \\
\hline & $A / G$ & 0.81 & 0.34 & 0.57 & - & - & - \\
\hline & $G / G$ & 0.05 & 0.13 & 0.09 & 0.46 & 0.29 & 0.37 \\
\hline \multirow[t]{3}{*}{$X R C C 3$} & $\mathrm{C} / \mathrm{C}$ & 0.81 & 0.85 & 0.83 & 0.90 & 0.92 & 0.91 \\
\hline & $\mathrm{C} / \mathrm{T}$ & 0.18 & 0.14 & 0.16 & - & - & - \\
\hline & $\mathrm{T} / \mathrm{T}$ & 0.01 & 0.01 & 0.01 & 0.10 & 0.08 & 0.09 \\
\hline
\end{tabular}


Table 5. Association between DNA repair genes and retinoblastoma risk among cases and controls. 


\begin{tabular}{|c|c|c|c|c|c|c|}
\hline Gene / & Genotypes & Cases & Controls & OR & $95 \% \mathrm{Cl}$ & p-value \\
\hline Polymorphism & & $\mathrm{n}=90(\%)$ & $\mathrm{n}=80(\%)$ & & & \\
\hline ERCC2 & $A / A$ & $67(74.44)$ & $61(76.25)$ & \multicolumn{3}{|c|}{ Reference (1.0) } \\
\hline \multirow{3}{*}{ rs13181 } & $\mathrm{A} / \mathrm{C}$ & $23(25.56)$ & $19(23.75)$ & 1.12 & $0.55-2.22$ & 0.86 \\
\hline & $\mathrm{C} / \mathrm{C}$ & $0(0.0)$ & $0(0.0)$ & - & - & - \\
\hline & $A / C+C / C$ & $23(25.56)$ & 19 (23.75) & 1.12 & $0.55-2.22$ & 0.86 \\
\hline \multirow[t]{4}{*}{ MSH2 rs 2303428} & $\mathrm{C} / \mathrm{C}$ & $81(90)$ & $73(91.25)$ & \multicolumn{3}{|c|}{ Reference (1.0) } \\
\hline & $\mathrm{C} / \mathrm{T}$ & $9(10)$ & $6(7.50)$ & 1.43 & $0.46-3.92$ & 0.60 \\
\hline & $\mathrm{T} / \mathrm{T}$ & $0(0.0)$ & $1(1.25)$ & - & - & - \\
\hline & $\mathrm{C} / \mathrm{T}+\mathrm{T} / \mathrm{T}$ & $9(10)$ & $7(8.75)$ & 1.16 & $0.41-3.24$ & 0.82 \\
\hline RAD54 & $\mathrm{C} / \mathrm{C}$ & $81(90)$ & $68(85)$ & \multicolumn{3}{|c|}{ Reference (1.0) } \\
\hline \multirow{3}{*}{ rs1048771 } & $\mathrm{C} / \mathrm{T}$ & $9(10)$ & $12(15)$ & 0.63 & $0.25-1.52$ & 0.36 \\
\hline & $\mathrm{T} / \mathrm{T}$ & $0(0.0)$ & $0(0.0)$ & - & - & - \\
\hline & $\mathrm{C} / \mathrm{T}+\mathrm{T} / \mathrm{T}$ & $9(10)$ & $12(15)$ & 0.63 & $0.25-1.52$ & 0.36 \\
\hline$X P C$ & $\mathrm{~A} / \mathrm{A}$ & $21(23.33)$ & $30(37.50)$ & \multicolumn{3}{|c|}{ Reference (1.0) } \\
\hline \multirow{3}{*}{ rs2228001 } & $\mathrm{A} / \mathrm{C}$ & $52(57.77)$ & $43(53.75)$ & 1.73 & $0.87-3.44$ & 0.16 \\
\hline & $\mathrm{C} / \mathrm{C}$ & $17(18.90)$ & $7(8.75)$ & 3.47 & $1.22-9.84$ & $0.03^{a}$ \\
\hline & $A / C+C / C$ & $69(76.66)$ & $50(62.50)$ & 1.97 & $1.01-3.84$ & 0.07 \\
\hline$X P G$ & $\mathrm{G} / \mathrm{G}$ & $28(31.11)$ & $14(17.50)$ & \multicolumn{3}{|c|}{ Reference (1.0) } \\
\hline \multirow{3}{*}{ rs17655 } & $\mathrm{G} / \mathrm{C}$ & $61(67.77)$ & $65(81.25)$ & 0.47 & $0.23-0.97$ & 0.06 \\
\hline & $\mathrm{C} / \mathrm{C}$ & $1(1.12)$ & $1(1.25)$ & 0.52 & $0.03-8.61$ & 1 \\
\hline & $G / C+C / C$ & $62(68.88)$ & $66(82.50)$ & 0.47 & $0.23-0.97$ & 0.06 \\
\hline$X R C C 1$ & $\mathrm{~A} / \mathrm{A}$ & $12(13.33)$ & $43(53.75)$ & \multicolumn{3}{|c|}{ Reference (1.0) } \\
\hline \multirow{3}{*}{ rs25487 } & $A / G$ & $73(81.11)$ & $27(33.75)$ & 9.74 & $4.45-21.08$ & $<0.01^{\mathrm{a}}$ \\
\hline & $\mathrm{G} / \mathrm{G}$ & $5(5.56)$ & $10(12.50)$ & 1.82 & $0.51-6.25$ & 0.49 \\
\hline & $A / G+G / G$ & $78(86.66)$ & $37(46.25)$ & 7.55 & $3.57-16$ & $<0.01^{\mathrm{a}}$ \\
\hline$X R C C 3$ & $\mathrm{C} / \mathrm{C}$ & $73(81.11)$ & $68(85)$ & \multicolumn{3}{|c|}{ Reference (1.0) } \\
\hline \multirow{3}{*}{ rs861539 } & $\mathrm{C} / \mathrm{T}$ & $16(17.77)$ & $11(13.75)$ & 1.36 & $0.59-3.13$ & 0.53 \\
\hline & $\mathrm{T} / \mathrm{T}$ & $1(1.12)$ & $1(1.25)$ & 0.93 & $0.06-15.22$ & 1 \\
\hline & $\mathrm{C} / \mathrm{T}+\mathrm{T} / \mathrm{T}$ & $17(18.88)$ & $12(15)$ & 1.31 & $0.59-2.92$ & 0.55 \\
\hline
\end{tabular}

$\mathrm{OR}$, odds ratio; $\mathrm{Cl}$, confidence intervals; $\mathrm{n}$, number of individuals.

a Significant

Figures 


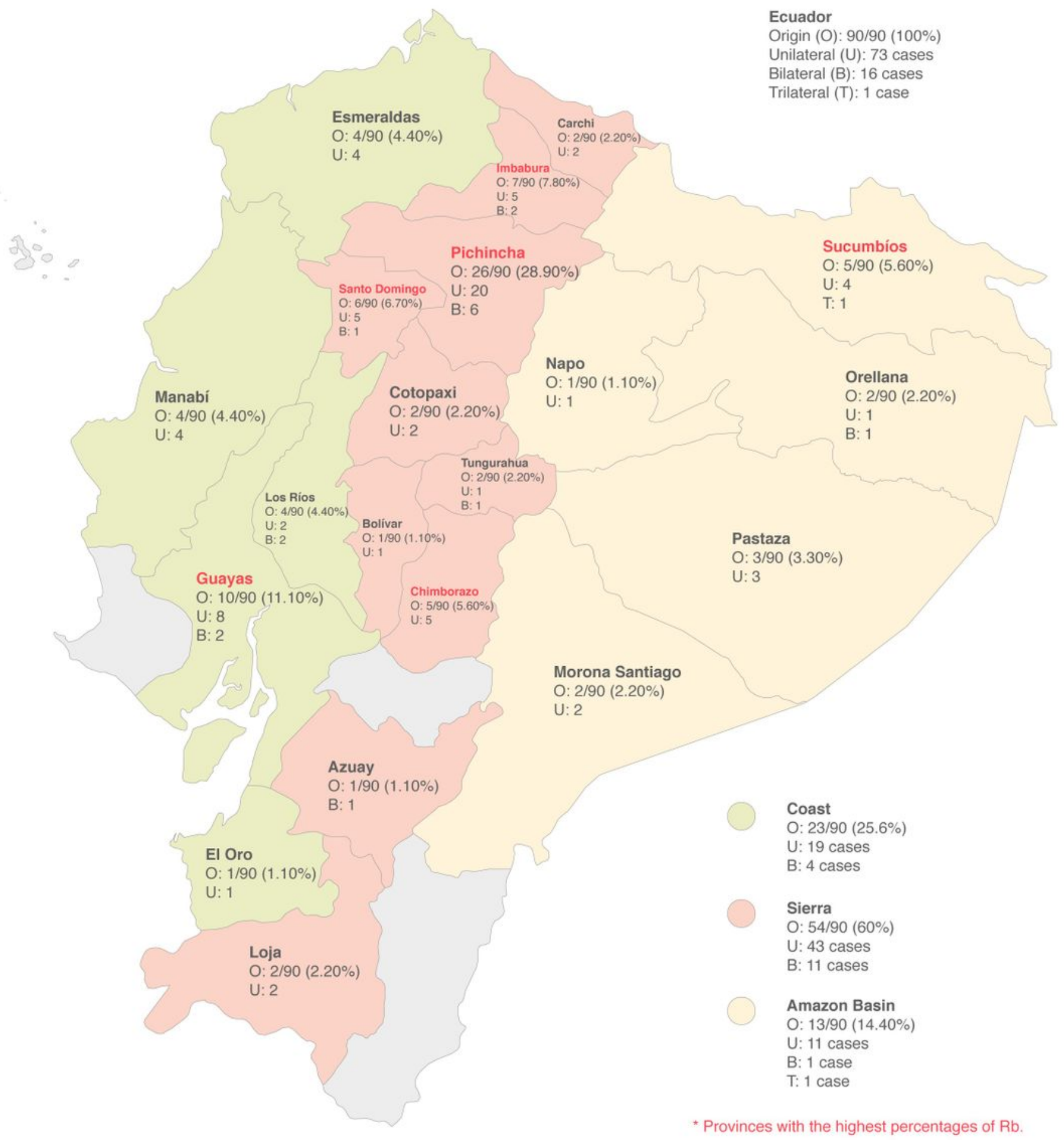

\section{Figure 1}

Distribution and laterality of $\mathrm{Rb}$ cases in Ecuador. 